This is an Accepted Manuscript of a book chapter published by Routledge in Weiss, Thomas G. and Wilkinson, Rorden, (eds.), International

\title{
Global energy governance
}

\section{Harald Heubaum}

Organization and Global Governance, 2nd edition, 2018. London:

Routledge, pp. 681-693

https://doi.org/10.4324/9781315301914-56

Accepted version downloaded from SOAS Research Online: http://eprints.soas.ac.uk/35183

The world economy is heavily reliant on the uninterrupted flow of energy. Without its mass production and consumption, there would be no modern economic growth and prosperity, no global trade in goods and services, no modern warfare, and no climate crisis threatening to undermine decades of human progress in health and development. Few countries are blessed with sufficient energy resources to fully meet the needs of their citizens, businesses and industry, and establishing a degree of energy security by gaining reliable and affordable access to these sources, especially fossil fuels, has come at a price. So have the impacts produced by fossil fuel combustion since the Industrial Revolution which can only be effectively addressed through a fundamental restructuring of the global economy.

In short, energy as a policy issue cuts across a number of different dimensions and has been described as "among all policy fields exhibiting externalities of a global scale, by far the most complex, path dependent, and embedded." Given its critical position at the very heart of global economics, politics and society, energy naturally lends itself to be governed at the global level. Yet such governance has so far remained largely elusive, with states jealously guarding their autonomy over energy policy and intergovernmental organizations operating in this field only recently starting to cooperate more closely.

This chapter begins by charting the emergence of the existing global energy governance architecture, understood here as the "overarching system of public and private institutions that are valid or active" in the energy field. ${ }^{2}$ This architecture is fragmented in that it consists of different parts with often only little interaction, let alone integration, between them. The first section focuses on intergovernmental energy organizations which trace their origins to the post-WWII emergence of producers in the Global South; their challenge to the then dominant western oil majors; and the impact on oil-consuming advanced economies in the Global North of the former's clout in world politics of the 1970s. However, there are also other intergovernmental energy organizations, among them the International Renewable Energy Agency (IRENA), which form part of the architecture of global energy governance and will be 
discussed here briefly. The chapter then proceeds to take a closer look at the UN and the role of several of its constituent parts in governing energy. The UN is often mistakenly overlooked in energy governance studies as it doesn't have a dedicated energy program. However, the climate negotiation process coordinated by the 1992 United Nations Framework Convention on Climate Change (UNFCCC), the 2015 Sustainable Development Goals (SDGs) and the activities of the World Bank have direct and meaningful implications for energy policymaking and investment around the world. The third section examines the benefits and challenges of building a global energy governance architecture that is more integrated internally while at the same time better able to capitalize on overlaps and synergies with other global policy domains, especially those in climate change and international development. The chapter concludes with an assessment of the future of global energy governance, including the prospects for a World Energy Agency.

\section{The landscape of global energy governance}

The governance of energy encompasses multiple actors in both the public and private spheres, operating on different levels from the international to the local. States determine the legal and regulatory environment within which energy markets operate. Both states and companies cooperate across borders, for example in the trade of oil and natural gas via pipelines, and the construction of renewable or nuclear power plants. At the international level, however, there are governance problems and effective coordination has proved difficult. Since the 1960s and 1970s, the architecture of global energy governance has evolved in a way that is marked by horizontal fragmentation, with the establishment of a number of intergovernmental organizations set up to address different sets of concerns over the supply and demand of energy.

Unlike the global climate governance architecture which revolves around the UNFCCC as its main pillar, there is currently no single, core institution in the field of global energy governance that incorporates (almost) all countries and has the power to help set binding rules and principles for its members. Instead, a division between oil-consuming advanced economies in the Global North and oilproducing developing economies in the Global South has troubled global energy governance from the 
beginning, the former embodied in the International Energy Agency (IEA) and the latter represented by the Organization of the Petroleum Exporting Countries (OPEC). The antecedents of this split reach back to the early years of the twentieth century. In what became one of the major turning points of global history, oil was discovered in 1908 in southwest Iran by William Knox D'Arcy - later director of the newly-founded Anglo-Persian Oil Company - putting the Middle East on the energy map.

\section{Oil producers in the Global South}

Together with Royal Dutch Shell and the five largest American oil companies to have emerged from the breakup of Standard Oil in 1911, Anglo-Persian Oil (later renamed "British Petroleum" (BP)) formed a powerful cartel of multinational oil companies commonly referred to as the Seven Sisters. ${ }^{3}$ These seven companies came to dominate the global petroleum industry in the first half of the twentieth century, controlling the vast majority of global oil reserves as well as mid- and downstream assets. The five American Sisters had built their power not on exploring and developing oil fields in the Middle East but on operations in the United States, then the world's largest oil producer. From their home base, they used their wealth and political influence to fend off unwanted competition and deepen control over petroleum projects elsewhere.

The Second World War fundamentally reshaped global geopolitics, laying the groundwork for a global energy governance architecture to emerge in the decades that followed. The rapid decline of the British Empire in particular had far-reaching consequences, with a large number of countries in the developing world gaining their independence, among them many of the oil-rich states of the Greater Middle East. OPEC was founded by Iran, Iraq, Kuwait, Saudi Arabia and Venezuela in 1960 in Baghdad. Its goal was to coordinate and unify the petroleum policies of the five founding members and support their economic interests on an international stage. In 1960, the Seven Sisters were still the key players in the global oil game but by the end of the decade, OPEC and especially Saudi Arabia with its large spare capacity, had replaced the United States as the global swing producer.

The Sisters were in for trouble when in 1968, the OPEC cartel, now counting 10 members, published a Declaratory Statement underlining the right of states to fully control their domestic 
resources. ${ }^{4}$ This move towards resource sovereignty culminated in a wave of nationalizations of domestic oil industries beginning in the 1970s. Within years it would end the dominant position of western multinational oil companies, putting OPEC states firmly in charge of their own energy affairs. For many years afterwards, the organization's influence derived from its ability to quickly curb or ramp up oil production and, due to its large share of global supplies, help determine oil prices.

In 1973, Arab members of OPEC used this "oil weapon", declaring an embargo against the United States and other western countries in response to their support of Israel in the Yom Kippur War. ${ }^{5}$ The resulting cut in oil production and increased costs had dramatic effects on oil-importing advanced economies, pushing many of them into recession. Since the 1990s, however, relations between oil producers in the Global South and consumers in the Global North have been less contentious, despite seismic events such as the 1990/91 Persian Gulf War and the 2003 invasion of Iraq.

OPEC today counts 13 members, representing the major oil producing countries in the Middle East, Africa and Latin America, and it is faced with a range of new challenges, among them the rise of non-OPEC oil producers, including the re-emergence of the United States as a leading shale oil producer. A period of high oil prices that began with a sudden spike - followed by an equally sudden temporary drop - at the height of the global financial crisis in 2008/09 incentivized increased production around the world. This revived the fortunes of previously uneconomic projects, made new exploration economically viable and provided additional volumes to the global oil market.

It is, in large measure, because of these developments that OPEC's ability to influence oil prices is today much reduced compared to the height of its power four decades ago. The growing urgency of addressing global climate change and the resulting need to shift energy systems away from a reliance on emissions-intensive hydrocarbons, too, is putting increasing pressure on the organization's members.

\section{Oil consumers in the Global North}

The International Energy Agency (IEA), widely considered the key organization in the fragmented landscape of global energy governance, was established in 1974 as an autonomous organization within the framework of the Organization for Economic Cooperation and Development (OECD), membership of 
which is a precondition for membership of the Agency. Its founding was a reaction to the 1973/74 oil crisis and the inability of the world's major oil consumers in the OECD to effectively counter its impacts on their respective economies. OECD members initially failed to react in a coordinated fashion, engaging instead in a panicked stockpiling of oil reserves which drove costs up even further. ${ }^{6}$

The IEA's original role was, thus, to prevent similarly problematic behavior in the face of future oil supply crises. The IEA's founding document lists the aims of the Agency as helping OECD countries develop self-sufficiency in oil in case of an emergency, establish oil demand limitation measures, gather and share information on developments in the international oil market, coordinate effective collective long-term responses to oil import dependence, and build closer relations between oil-consuming and oilproducing countries. ${ }^{7}$ Today, the 29 member states are required to hold sufficient oil reserves to maintain consumption for at least 90 days without further oil imports. ${ }^{8}$ In the years since the IEA's founding, oil from this strategic reserve has been released three times: at the outset of the 1991 Persian Gulf War; after Hurricane Katrina had wreaked havoc in the Gulf of Mexico, destroying critical oil production infrastructure in the process; and in 2011 in response to the civil war in Libyan and the bombing campaign led by the North Atlantic Treaty Organization (NATO) under a UN mandate.

However, the global energy landscape has changed considerably since the early 1970s, with oil retaining its critical importance for transportation but falling out of favor in the power sector. OECD members increasingly pursued policies aimed at incentivizing a greater diversity of energy sources and addressing new threats and opportunities beyond the petroleum industry. The IEA responded to these changes by broadening its approach, incorporating into its portfolio such issues as natural gas, nuclear power and, more recently, renewable energy sources, energy efficiency, sustainable development and environmental protection. In parallel, the Agency's senior management has become more vocal over time, voicing strong support for greenhouse gas $(\mathrm{GHG})$ emissions reductions in line with the targets spelled out in the Paris Agreement on climate change. ${ }^{9}$ But while these developments provide evidence for the IEA exercising its organizational autonomy in a fast-changing global policy environment, there are limits to what it can effectively achieve. Apart from its coordination during oil supply emergencies, the Agency's main role is of an advisory, training and information-gathering nature. For example, it does not have 
authority over the domestic energy policies of its members on whom it also depends for the bulk of its budget - limitations it shares with other intergovernmental organizations populating the landscape of global energy governance. Further, the restrictions imposed on the Agency by its OECD-only membership risk leaving many of the world's biggest energy consumers, including China and India, outside emerging governance arrangements, making it harder to move towards a more integrated architecture.

\section{Beyond the IEA-OPEC divide}

The global energy governance landscape also comprises a number of other, less well-known intergovernmental organizations, some of which straddle the divide between major oil producers in the Global South and oil-consuming advanced economies in the Global North. These include the Latin American Energy Organization (OLADE) founded in 1973, the Energy Charter Treaty (operational since 1998) and the Gas Exporting Countries Forum (GECF) established in 2001. With its focus on renewable energy, IRENA joined the group of intergovernmental organizations working on energy in 2009. Of all the organizations focused on specific energy sources, IRENA has the broadest membership with 150 full state members and a further 30 candidates (as of June 2017). Headquartered in Abu Dhabi, it is the intergovernmental energy organization that most clearly transcends the North-South divide. The Agency is the only major international forum exclusively addressing renewable energy sources.

Unlike the IEA which, by virtue of a broad-based portfolio, does not pick and choose particular energy technologies over others, IRENA was founded with the express goal of promoting the increased adoption of renewables around the world. ${ }^{10}$ This was in large part due to a sense of frustration among some of the founding states - Germany, Denmark and Spain - that the IEA, of which they are members, remained too closely wedded to fossil fuels and did not sufficiently acknowledge the growth and future potential of renewables such as wind and solar photovoltaics. ${ }^{11}$ However, compared to the more established intergovernmental energy organizations, IRENA has fewer staff and resources at its disposal, limiting its ability to play a greater role in the debate and make a more powerful case for a renewable energy transition. 
In addition, a number of intergovernmental organizations have emerged as important actors in global energy governance, even though they were not founded to specifically address energy issues. For example, the Shanghai Cooperation Organization (founded in 2001), whose primary focus is on strengthening mutual trust and friendship among its members and enhancing regional security, brings together a number of Asian energy-producing and consuming countries such as China, Russia and Kazakhstan. Its members have cooperated on a range of energy issues, particularly regarding fossil fuels. The Asia-Pacific Economic Cooperation (APEC) established its Energy Working Group in 1990, which has since met 47 times. APEC has also convened 12 Energy Ministerial Meetings since 1996 to discuss a range of issues such as energy infrastructure investment, oil prices, low-carbon sustainable energy development in the Asia-Pacific, or energy security and resilience, the focus of the 12th Energy Ministerial Meeting held in Cebu, the Philippines. The Association of Southeast Asian Nations (ASEAN) has been involved in energy issues since the late 1990s, when it created the Centre for Energy to improve coordination and cooperation among its members in the energy field. The European Union (EU) has worked on the supranational level to coordinate energy policies among its member states through the Common Energy Policy and the 2015 Energy Union Strategy. Finally, the landscape of global energy governance is further populated by summit processes such as the G7/G8 and the G20, both of which have provided vital high-profile forums for the discussion of issues such as energy efficiency, the phasing out of fossil fuel subsidies and cutting carbon dioxide emissions.

The large number of organizations in global energy governance makes a truly global approach to energy production and consumption - uniting producers and consumers in North and South under a shared set of rules and principles - next to impossible. A highly fragmented energy governance architecture also hinders moves to integrate and effectively coordinate responses to the intertwined challenges of energy security and climate change. Global energy governance is further complicated by vertical fragmentation, which plays an important role, notably regarding the often uneasy relationship between actors operating in global and regional energy markets and governments' attempts to regulate their behavior at the domestic or supranational level. 


\section{The United Nations}

While without a dedicated energy program, the UN nonetheless addresses energy with regards to economic, social and environmental sustainability through a number of different organizations and programs, including the United Nations Industrial Development Organization (UNIDO), the United Nations Development Program (UNDP) and the United Nations Environment Program (UNEP). The United Nations Statistics Division (UNSD) gathers energy statistics from over 190 countries, with a database reaching back to the 1950s. The International Atomic Energy Agency (IAEA) has been the focal point for international cooperation in the nuclear field since its founding in 1957, preceding the creation of OPEC and the IEA. As an autonomous intergovernmental forum within the UN family, the IAEA reports to both the General Assembly and the Security Council and it has played a critical role with regards to the safe and peaceful use of nuclear energy technologies and nuclear non-proliferation. ${ }^{12}$

With the 2004 establishment of UN-Energy as a mechanism for inter-agency collaboration on energy issues, the UN has attempted to connect up its various internal activities. In theory, the creation of such a mechanism is useful if only to avoid duplication of efforts by different parts of the UN family and save scarce resources. However, UN-Energy has so far lacked the sustained high-level support to enable it to live up to its full intended purpose. Similarly, the Sustainable Energy for All (SE4ALL) initiative launched in 2011 by then Secretary General Ban Ki-moon with the goal of achieving universal sustainable energy access had only little tangible impact until the adoption of the SDGs in 2015.

\section{Climate change negotiations}

International climate change negotiations take place under the roof of the UNFCCC, one of the outcomes of the 1992 UN Conference on Environment and Development in Rio de Janeiro. Most accounts of global energy governance make no direct mention of the UNFCCC and the results the negotiation process has produced over the last two decades. And yet the Paris Agreement on climate change, as an international agreement within the UNFCCC, is, in its implications, the most profound and far-reaching energy - and economic - treaty the world has ever seen. Staying well below a $2^{\circ} \mathrm{C}$ rise in global average surface temperatures above pre-industrial levels, as prescribed by the agreement,${ }^{13}$ requires a swift 
decarbonization of energy systems around the world, major changes in the production and consumption not just of energy but of goods more generally, and the mobilization of large amounts of public and private capital to achieve the necessary changes. The actions parties intend to take under the Paris Agreement, referred to as Nationally Determined Contributions (NDCs), begin to spell out domestic pathways to collectively achieve global carbon neutrality by 2050 , with a strong focus on transitioning away from emissions-intensive fossil fuels towards renewables and other low-carbon energy technologies such as carbon capture and storage (CCS) and nuclear power. This, in turn, has direct implications for all other aspects of global energy governance, emphasizing the need to understand energy and climate change as interconnected challenges.

The guarded optimism about this multilateral agreement, however, was dampened by the Trump administration's June 2017 announcement that the United States would withdraw from the Paris Agreement. The decision will not go into effect until 2021, leaving the possibility for a return should a new US president be elected prior to that date.

\section{Sustainable development}

With the adoption of the SDGs, the UN has sought not only to continue and build on work left unfinished by the preceding Millennium Development Goals (MDGs), but also to expand the scope of measures needed "to free the human race from the tyranny of poverty and want and to heal and secure our planet." 14 While the MDGs failed to mention energy at all, goal seven of the new SDGs concerns itself exclusively with affordable energy access, energy efficiency and clean energy infrastructure. Goal 13, with its focus on climate action addresses energy as the main source of GHG emissions and reiterates earlier calls for a further development of renewables.

It has been argued that the majority of the SDGs are now either "wholly or partially concerned with managing resources, energy or climate change" given the strong environmental connotations of "sustainability." 15 Beyond mere semantics, however, the emphasis on energy and climate change is logical and consequential, as success in addressing many of the development goals and targets is directly dependent on the reliable provision of sufficient amounts of energy at affordable prices, and on whether 
or not the growth in global carbon dioxide $\left(\mathrm{CO}_{2}\right)$ emissions can be sufficiently reined in to slow the rise in global average surface temperatures.

With its focus on development support and poverty reduction in the Global South, the World Bank may not seem, at least initially, to be a key player in global energy governance. Yet due to the interconnection between energy provision and economic development, one of the Bank's biggest budget lines has long been lending for energy infrastructure projects. Together with the closer integration and expansion of the climate change portfolio into its core agenda, the Bank, as part of the UN family, is a powerful player in supporting countries' efforts to build greater domestic power generation capacity while transitioning towards a sustainable, low-carbon energy future.

The SDGs are a reflection of a new reality in international development which acknowledges climate change and energy as key dimensions that need to be jointly addressed if there is to be meaningful progress overall. In this same vein, the activities of the World Bank are now unthinkable without a significant focus on the two interconnected issue areas. This is a change from the past when the Bank was widely criticized for investments in unsustainable high-emissions energy infrastructure, especially coalfired power generation. But in a sign of the changing times, in 2016 World Bank President Jim Yong Kim warned of the construction of further coal-fired power plants if GHG targets were to be met and the World Bank Group published a Climate Change Action Plan designed to help countries meet their NDCs and invest more heavily in low-carbon energy solutions in the period up to $2020 .{ }^{16}$ The Bank shares this new approach with other international financial institutions such as the Asian Development Bank (ADB) whose lending has shifted from support for fossil fuel projects towards renewables, energy efficiency and sustainable transport in line with new global priorities spelled out in the Paris Agreement and the SDGs. ${ }^{17}$

\section{Towards an integrated architecture?}

For global energy governance to be more effective, two main challenges need to be addressed going forward. First, the various intergovernmental organizations making up the energy landscape need to be integrated into a more coherent architecture. Second, the remaining divides between energy governance 
and other global governance fields, such as those in climate change and international development, need to be bridged further in order to capitalize on existing overlaps and synergies.

Given the diversity of energy sources and technologies and the varied energy interests of states in the international system, a further integration and potential unification of the fragmented landscape of global energy governance can only occur around an intergovernmental organization or group of organizations that addresses the whole breadth and scope of energy policy today. This rules out OPEC as a suitable conduit for integration as its important but narrow focus on high-carbon petroleum products fails to adequately reflect the low-carbon direction of travel for the world's energy systems. But while global power generation is diversifying and transitioning towards renewable sources in many countries,

fossil fuels and nuclear power will continue to play an important role for some time to come, especially if technological innovations such as CCS can be cost-effectively applied at industrial scale. Therefore, even though IRENA will have a vital part to play in the global energy governance architecture, it, too, cannot currently serve as its main pillar. This leaves the IEA as the only widely respected and distinctly energyfocused organization with a broad enough issue portfolio to potentially take on such a role.

\section{Integration within global energy governance}

One of the keys to unlocking greater integration within global energy governance is greater cooperation between the IEA and IRENA. The "salutary shock" provided by the creation of IRENA as a potential rival organization in 2009 had an undeniable impact on the IEA and led it to pay closer attention to renewable energy sources. ${ }^{18}$ Renewables play a much bigger role in the IEA's issue portfolio today than ten years ago. Renewable technology reports acknowledging the rapid scaling up and increasing costcompetitiveness of wind and solar PV are now issued on a regular basis. In early 2012, the two organizations signed an official partnership agreement, targeting the development and publication of the IEA/IRENA Global Renewable Energy Policies and Measures Database, cooperation in technology and innovation, and the sharing of renewable energy statistics. Both organizations have also held joint workshops and co-published a number of energy technology briefs. In early 2017, in a historic move, the 
IEA and IRENA published their first ever joint report focused on a global decarbonization of the energy sector.

Since the 1990s there has also been an improvement in relations between the IEA and OPEC. The organizations and their members cooperate via the International Energy Forum (IEF). Both the IEA and OPEC were founding members of the Joint Organizations Data Initiative which was created as a permanent mechanism by the IEF to arrive at more reliable statistics for petroleum and natural gas and also includes APEC, OLADE, the Statistical Office of the European Communities (EUROSTAT), GECF and UNSD. There are, however, limits to the partnership between the IEA and OPEC, as demonstrated in 2011. As the war in Libya drove up global oil prices, there was a failure to coordinate a joint response to the events. Attempts by consumer countries to get OPEC to increase its oil production quotas failed, prompting the IEA to release 60 million barrels from emergency stocks over the period of thirty days. In response, OPEC Secretary General Abdullah al-Badri complained that strategic oil reserves should not be "used as a weapon against OPEC." 19 The dispute threatened the rapprochement between the organizations and served as a reminder of the potential for conflict in the fragmented global governance architecture.

Although membership of the IEA is limited to OECD countries, the organization has recently stepped up cooperation with major non-member energy producers and consumers around the world, particularly its seven partner countries in the G20 - China, India, Brazil, Mexico, Indonesia, South Africa and Russia - as well as with selected member states of the Association of Southeast Asian Nations (ASEAN). This cooperation has gone beyond the issuing of occasional reports. The seven G20 partner countries actively participate in the IEA Ministerial Meeting which takes place every two years and sets broad strategic priorities for the Agency. The IEA's data modelling and statistics courses are designed for and attended by government representatives from non-member countries. In late 2013, the IEA and its partner countries (with the exception of Mexico) issued a Joint Declaration on Association which stated their mutual interest "to pursue closer cooperation on the basis of a common understanding that global energy challenges and energy security require shared solutions by producer, consumer and transit countries." ${ }^{20}$ Since 2015, China, Indonesia, Thailand, Singapore, Morocco and India have all become Association countries in an important further step towards expanding the IEA's reach beyond its 
traditional OECD membership and bridging the North-South divide. However, while ties have deepened with several major countries, they have threatened to break with others. The political fallout of the Ukraine crisis in 2014, the resulting sanctions imposed by western countries on Russia and a heated debate over the EU's continued dependence on Russian gas have all undermined the growing relationship.

\section{Integration between different governance architectures}

While climate change wasn't an issue occupying international policymakers' attention in the infant days of global energy governance, it has since become a key determinant of policymaking around the world, reaching far beyond its more obvious environmental and energy policy implications. The intergovernmental organizations making up the global energy governance architecture have had to adjust to this new reality and address climate change as an integral part of their activities. The consequence has been a greater interaction and growing integration between global energy and global climate governance. With its focus on renewable energy technologies and advocacy for a sustainable, low-carbon energy future, IRENA has been a natural partner for the UNFCCC and the wider climate change field since its creation in 2009 .

In contrast, the IEA, as the significantly older and more established intergovernmental energy organization, underwent a period of transition to arrive in a similar place. The IEA significantly expanded its focus on climate change following the $2005 \mathrm{G} 8$ summit at Gleneagles and now gathers $\mathrm{CO}_{2}$ emissions statistics, maintains a database on GHG emissions policies undertaken by member states and has devoted substantial and growing attention to the issue in all its World Energy Outlooks (WEO) - the organizations' annual flagship publication - since 2008. The IEA's leadership around Executive Director Fatih Birol and his predecessor Maria van der Hoeven became much more outspoken on climate change over time, making the case for an aggressive reduction of global GHG emissions in line with the $2^{\circ} \mathrm{C}$ stabilization target spelled out in the Paris Agreement. The IEA now officially supports the UNFCCC in a number of its functions, including expert review of emissions data and climate policy measures, technical examination of decarbonization efforts and the mobilization of private capital for clean energy projects in developing countries. Like IRENA, the IEA is represented at Conferences of the Parties (COPs) to the 
UNFCCC and is a respected go-to for the kind of energy policy knowledge often lacking among many of the environmental experts supporting the climate convention process.

In the sustainable development arena, too, the cooperation between intergovernmental energy organizations and the UN family has increased over time. This is only logical considering IRENA's global membership and the countries working with the IEA on an association basis. As a UN observer, IRENA works closely with UNDP and the World Bank, among others, with regards to financing of renewable energy projects and widening energy access in the developing world. The IEA has cooperated with UN actors on issues of energy poverty and universal energy access for years, drawing on its substantial work in the field since the 1990s, a cooperation boosted by the proclamation of the SDGs with their strong focus on energy and climate change. In addition, the heads of the IEA and the World Bank have both repeatedly called for an end to fossil fuel subsidies around the world, following a number of joint reports on the issue prepared for the G20 since the forum's 2009 commitment to phase out such subsidies over the medium term.

\section{Conclusion}

The future of global energy governance remains uncertain. Since the 1960s, a fragmented landscape comprising a variety of different intergovernmental organizations has emerged which has lately shown movement towards greater cooperation and integration. Yet how far these developments may lead cannot yet be determined. Should there be a de facto or de jure "World Energy Agency", either by adding new members (fully or on an association basis) to the IEA or should the Agency open up to all non-member countries, turning itself into a universal international organization? Would this improve the integration of the different organizations within the global energy governance architecture? Would it improve the integration of global energy and climate governance architectures? Would such a World Energy Agency need the power to set binding rules for its members and associated partners? Would countries willingly abide by those rules? Should a World Energy Agency be placed under the UN?

Powerful obstacles currently impede the establishment of a World Energy Agency. These include membership in the OECD as a legal precondition for full membership in the IEA; continuing conflicts of 
interest between energy consumer and energy producer countries, with the latter continuing their cooperation in organizations such as OPEC; and the requirement for IEA member states to maintain and finance a costly strategic oil reserve. They also include the political rifts between major energy producers such as Russia and consumer countries in the OECD, which have surfaced in the last few years.

However, it is not inconceivable that a World Energy Agency, for example as the result of a future merger between the IEA and IRENA, could be placed on a new legal footing with updated statutes and adjusted organizational structures fit for the twenty-first century. But doing so would be dependent on sufficient political will among current IEA and IRENA members to accept the newly-created Agency's new role, and contribute to its success. In sum, from an aspirational perspective of effective global energy governance it seems desirable to have one single organization that covers all states, in the Global North and South, and that integrates all sources of energy. Yet given the various obstacles, path-dependencies, and lock-ins in current global energy governance, this seems far away. The IEA's current strategy of slowly moving in this direction and adjusting its approach in response to a fast-changing global policy environment, forging partnerships with other intergovernmental organizations as well as with nonmember states, appears to be the next-best option, possibly leading to further integration and reform in the years to come.

However, as the chapter has illustrated, the key players in global energy governance are not just intergovernmental organizations specifically focused on energy but also treaty processes such as the UNFCCC and internationally-agreed agendas such as the SDGs. The Paris Agreement on climate change would not normally be studied as an important part of the global energy governance architecture and yet its implications for energy systems and energy policymaking around the world - with or without the participation of the United States - reach far beyond the impact currently enjoyed by any of the major intergovernmental energy organizations. Likewise, the SDGs and, by extension the multilateral development banks working to deliver the ambitious new development agenda, are critically important if energy security and low-carbon energy transitions are to become a reality in the poorer states of the Global South as much as in the wealthier Global North. Therefore, a more holistic view of global energy 
governance is required. It should incorporate the various key actors and agreements that shape outcomes in this field regardless on which governance architecture they may be built.

\section{Additional reading}

1. Andreas Goldthau, The Handbook of Global Energy Policy (Chichester: Wiley-Blackwell, 2016).

2. Caroline Kuzemko, Andreas Goldthau and Michael E. Keating, The Global Energy Challenge:

Environment, Development and Security (Basingstoke: Palgrave Macmillan, 2015).

3. Thijs Van de Graaf, The Politics and Institutions of Global Energy Governance (Basingstoke: Palgrave Macmillan, 2013).

4. Daniel Yergin, The Quest: Energy, Security and the Remaking of the Modern World (London: Allen Lane, 2011).

\section{Notes}

\footnotetext{
${ }^{1}$ Andreas Goldthau and Benjamin K. Sovacool, "The uniqueness of the energy security, justice, and governance problem" Energy Policy 41 (2012), 232-240.

${ }^{2}$ For a more complete definition see Frank Biermann, et al., "The architecture of global climate governance: setting the stage," in
}

Biermann, F., Pattberg, P. and F. Zelli eds., Global Climate Governance Beyond 2012: Architecture, Agency and Adaptation (Cambridge: Cambridge University Press, 2010), pp. 15-24.

${ }^{3}$ Standard Oil of California, Standard Oil of New Jersey, Standard Oil of New York, Texaco, Gulf Oil, Royal Dutch Shell and the Anglo-Iranian Oil Company (the later BP). The American members of the group would later merge into the Chevron Corporation and ExxonMobil, respectively.

${ }^{4}$ Organization of the Petroleum Exporting Countries, "Guidelines for petroleum policy in member countries" International Legal Materials 7, no. 5 (1968), 1183-1186.

${ }^{5}$ Rüdiger Graf, "Making use of the 'oil weapon': Western industrialized countries and Arab petropolitics in 1973-74" Diplomatic History 36, no. 1 (2012), 185-208.

${ }^{6}$ Ann Florini and Benjamin K. Sovacool, "Who governs energy? The challenges facing global energy governance” Energy Policy 37, no. 12 (2009), 5239-5248. 
${ }^{7}$ Organisation for Economic Co-operation and Development, Decision of the Council establishing an International Energy Agency of the Organisation (Paris: OECD, 1974).

${ }^{8}$ As net-exporter members, Canada, Denmark and Norway are currently exempt from this arrangement.

${ }^{9}$ Harald Heubaum and Frank Biermann. "Integrating global energy and climate governance: The changing role of the International Energy Agency” Energy Policy 87 (2015), 229-239.

${ }^{10}$ International Renewable Energy Agency, Statute of the International Renewable Energy Agency (Bonn: IRENA, 2009).

11 Thijs Van de Graaf and Dries Lesage, “The International Energy Agency after 35 years: reform needs and institutional adaptability” The Review of International Organizations 4, no. 3 (2009), 293-317.

${ }^{12}$ International Atomic Energy Agency, Statute of the IAEA (Vienna: IAEA, 2016), https://www.iaea.org/about/statute

${ }^{13}$ United Nations Framework Convention on Climate Change, Paris Agreement (Bonn: UNFCCC, 2015).

http://unfccc.int/files/essential_background/convention/application/pdf/english_paris_agreement.pdf

${ }^{14}$ United Nations, "Transforming our world: the 2030 Agenda for Sustainable Development,” General Assembly Resolution (A/RES/70/1), 21 October 2015.

${ }^{15}$ Stephen Browne and Thomas G. Weiss, “The UN's post-2015 development agenda and leadership,” Great Decisions 2016, Foreign Policy Association (2016), https://www.futureun.org/media/archive1/reports/GreatDecisions_UN_Post2015.pdf ${ }^{16}$ Suzanne Goldenberg, "Plans for coal-fired power in Asia are 'disaster for planet' warns World Bank," The Guardian, 5 May 2016. See also: World Bank, World Bank Group Climate Change Action Plan 2016-2020 (Washington, DC: World Bank, 2016).

${ }^{17}$ Asian Development Bank, 2015 Clean Energy Investments Project Summaries (Manila: ADB, 2016).

18 Thijs Van de Graaf, "Fragmentation of global energy governance: Explaining the creation of IRENA," Global Environmental Politics 13, no. 3 (2013), 14-33.

${ }^{19}$ Barbara Lewis, “OPEC, IEA clash over oil reserves weapon,” Reuters, 23 June 2011.

${ }^{20}$ International Energy Agency, Joint Declaration by the IEA and Brazil, China, India, Indonesia, Russia and South Africa on the occasion of the 2013 IEA Ministerial Meeting expressing mutual interest in pursuing an association (Paris: IEA, 2013). 